\title{
Pengaruh inflasi dan laju pertumbuhan penduduk terhadap kemiskinan di Sumatera bagian Selatan Tahun 2011-2018
}

\author{
Kevin 1, Aning Kesuma Putri (iD)*1, \& Aja Nasrun² \\ ${ }^{1}$ Fakultas Ekonomi, Universitas Bangka Belitung, Indonesia \\ 2Badan Pusat Statisik Provinsi Kepulauan Bangka Belitung, Indonesia
}

\begin{abstract}
Abstrak Penelitian ini bertujuan untuk mengetahui pengaruh inflasi dan laju pertumbuhan penduduk terhadap kemiskinan di Sumatera bagian Selatan (Sumbagsel) tahun 2011-2018. Penelitian ini menggunakan pendekatan kuantitatif. Data yang digunakan adalah data panel ibu kota provinsi di Sumbagsel yang terdiri dari Palembang, Pangkalpinang, Bandar Lampung, Bengkulu, dan Jambi tahun 2011-2018. Teknik analisis data dalam penelitian ini menggunakan analisis regresi data panel dengan model Random Effect. Hasil penelitian menunjukkan bahwa secara simultan variabel inflasi dan laju pertumbuhan penduduk berpengaruh signifikan terhadap kemiskinan. Secara parsial variabel inflasi tidak berpengaruh signifikan terhadap kemiskinan sedangkan variabel laju pertumbuhan penduduk berpengaruh signifikan terhadap kemiskinan.
\end{abstract}

Kata kunci: pertumbuhan; inflasi; jumlah penduduk; kemiskinan; Sumatera

\begin{abstract}
This research aimed to find out the effect of inflation and population growth rate on the poverty in Southern Sumatera in 2011-2018. This research used the quantitative approach. The data used is panel data of the capital of province in Southern Sumatera which consists of Palembang, Pangkalpinang, Bandar Lampung, Bengkulu, dan Jambi in 2011-2018. The data analysis technique was the panel data regression analysis using random effect model. The result of the research showed that simultaneously the variable of inflation and population growth rate have a significant effect on the poverty. Partially the variable of inflation have no significant effect on the poverty while the variable of population growth rate has a significant effect on the poverty.
\end{abstract}

Keywords: growth; inflation; population; poverty; Sumatera

JEL Classification: Co1; E6o;I32 


\section{PENDAHULUAN}

Kemiskinan merupakan permasalahan utama dalam perekonomian di negara berkembang. Indonesia sebagai negara berkembang telah mengusahakan segala cara untuk mengurangi kemiskinan dengan mengeluarkan berbagai kebijakan dan bahkan telah menjadi masterplan perencanaan pembangunan dalam jangka panjang untuk meningkatkan perekonomian (Irhamni, 2017). Masyarakat dapat disebut sejahtera apabila masyarakat tersebut telah dapat memenuhi kebutuhan hidupnya secara mandiri. Permasalahan yang dihadapi oleh banyak negara yang menyangkut kesejahteraan masyarakat adalah ketidakmampuan masyarakat dalam memenuhi kebutuhan hidupnya (Suliswanto, 2010). Kemiskinan dapat terjadi karena anggota masyarakat tidak atau belum berpartisipasi dalam proses perubahan yang disebabkan ketidakmampuan dalam kepemilikan faktor produksi atau kualitas yang kurang memadai (Arsyad, 2010).

Secara konsep, kemiskinan dapat dibedakan menjadi kemiskinan absolut dan kemiskinan relatif. Kemiskinan absolut memandang kemiskinan dalam suatu ukuran yang besifat mutlak yang bermuara atau berwujud sebagai garis, titik, atau batas kemiskinan. Sementara kemiskinan relatif, memandang kemiskinan dalam suatu ukuran yang dipengaruhi ukuran-ukuran lain yang berhubungan dengan proporsi atau distribusi (Nugroho \& Dahuri, 2012). Terkait distribusi, Taryono et al. (2009) mengatakan perpindahan penduduk ke satu daerah berpengaruh terhadap kemiskinan di daerah yang dituju.

Beberapa provinsi di Pulau Sumatera memiliki tingkat kemiskinan yang tinggi, diantaranya berada di wilayah Sumatera bagian Selatan (Sumbagsel) yang meliputi Sumatera Selatan, Lampung, Jambi, Bengkulu, dan Kepulauan Bangka Belitung (Badan Pusat Statistik, 2019). Tingkat kemiskinan di beberapa provinsi wilayah Sumatera bagian Selatan digambarkan dalam grafik pada Gambar 1.

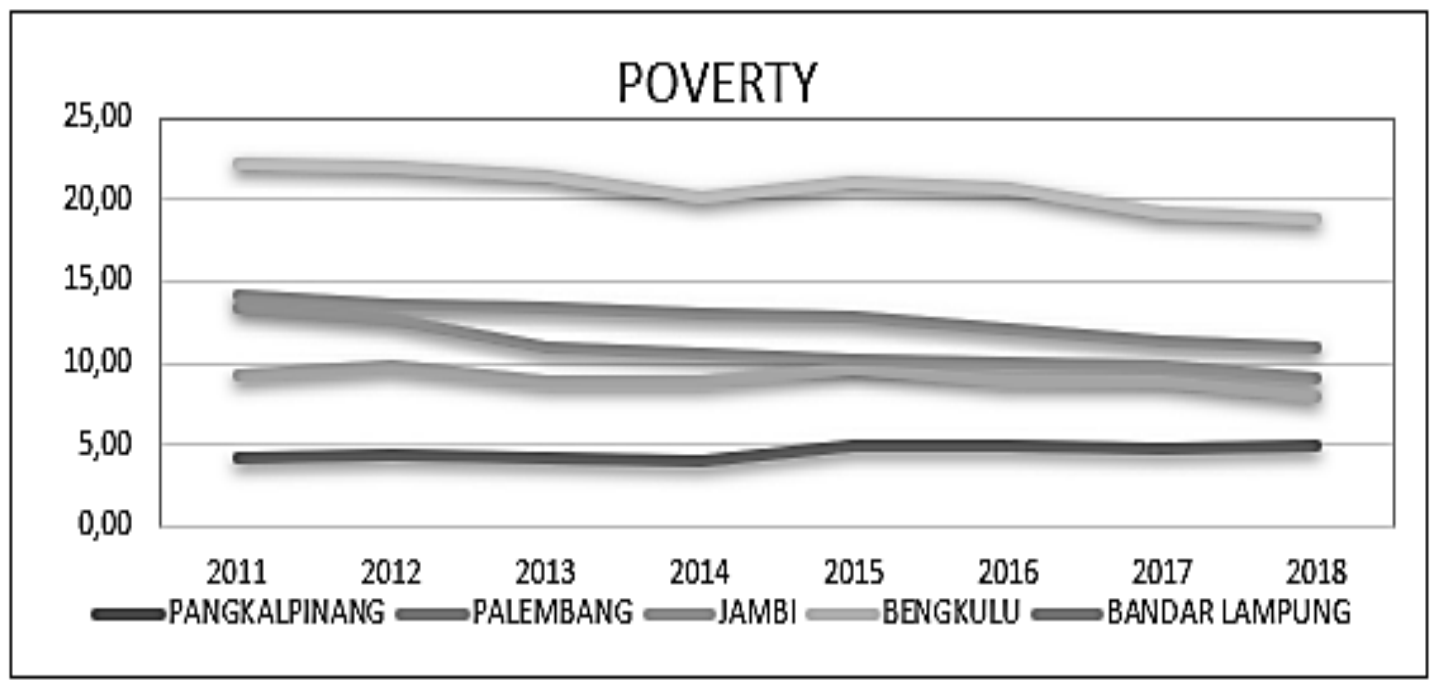

Sumber: Badan Pusat Statistik, diolah peneliti 2019

Gambar 1. Grafik persentase penduduk miskin di Sumbagsel 
Pada periode 2011-2018, persentase penduduk miskin terendah di wilayah Sumatera bagian Selatan berada di Kota Pangkalpinang dengan rata-rata 4,55 persen. Hal ini merupakan dampak dari kontribusi sektor unggulan industri pengolahan yang menjadi penyumbang Produk Domestik Regional Bruto (PDRB) terbesar yaitu mencapai 25,27 persen pada tahun 2011 dan 20,64 pada tahun 2018 . Sedangkan persentase penduduk miskin tertinggi berada di Kota Bengkulu dengan rata-rata 20,73 persen. Hal ini disebabkan karena harga kebutuhan pokok di Bengkulu lebih tinggi dari pendapatan masyarakat.

Salah satu faktor penyebab kemiskinan adalah inflasi. Inflasi adalah proses kenaikan harga-harga barang secara umum dan menyeluruh secara terus-menerus (Noripin, 2009). Jika inflasi tinggi namun pendapatan tetap, maka akan berdampak pada meningkatnya jumlah kemiskinan. Dapat dilihat pada Gambar 2 pergerakan inflasi di wilayah Sumbagsel yang fluktuatif sangat dipengaruhi oleh laju inflasi pada bahan makanan dan komponen barang-barang yang harganya ditetapkan pemerintah. Pada periode 2011-2018, inflasi tertinggi di wilayah Sumbagsel berada di Kota Bengkulu yaitu sebesar 10,85 persen pada tahun 2014 dan inflasi terendah berada di Kota Jambi pada tahun 2015 yaitu sebesar 1,37 persen. Sedangkan pada tahun 2016, inflasi tertinggi berada di Kota Pangkalpinang yaitu sebesar 7,78 persen. Namun kemiskinan di Kota Pangkalpinang tetap yang terendah, hal ini disebabkan karena inflasi diimbangi dengan peningkatan pendapatan masyarakat.

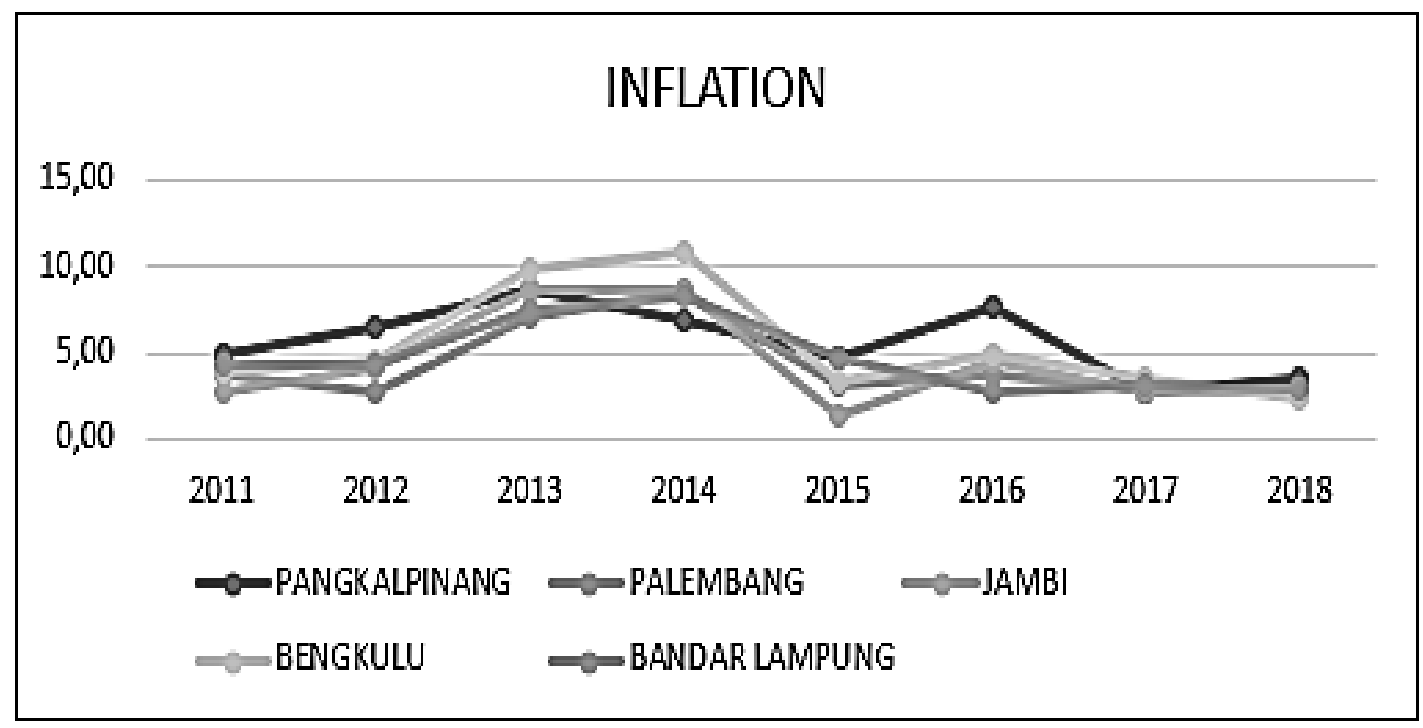

Sumber: Badan Pusat Statistik, diolah peneliti 2019

Gambar 2. Grafik inflasi di Sumbagsel

Sumber dan proses lain penyebab terjadinya kemiskinan, yaitu: population growth, perspektif yang didasari oleh teori Malthus bahwa pertambahan penduduk seperti deret ukur sedangkan pertambahan pangan seperti deret hitung (Nasikun, 2001). Permasalahan kemiskinan berkaitan dengan jumlah penduduk yang tinggi dan akan mengakibatkan bertambahnya jumlah angkatan kerja. Kenaikan jumlah penduduk yang terus-menerus dapat menimbulkan dampak yang buruk terhadap pertumbuhan ekonomi dan membuat prospek pembangunan menjadi lambat (Dumairy, 1996). Studi Isramiwarti et al. (2017) mengatakan pengeluaran daerah 
memiliki peran penting dalam meningkatkan pengaruh jumlah penduduk dalam mengurangi kemiskinan. Studi lainnya memperlihatkan lapangan kerja, potensi local, prasarana, dan alokasi dana pemerintah dapat berkontribusi mengentaskan kemiskinan (Syahza et al., 2018; Zebua et al., 2015; Zebua et al., 2017; Fatria, 2020). Kenaikan jumlah penduduk tanpa kemajuan faktor produksi yang lain akan menurunkan pendapatan dan permintaan, sehingga akan menurunkan tingkat upah dan biaya produksi. Biaya produksi yang rendah akan memperbesar keuntungan para kapitalis dan mendorong mereka untuk terus berproduksi. Tetapi hal ini hanya akan terjadi dalam waktu yang singkat, karena permintaan efektif (effective demand) akan semakin berkurang dan pendapatan buruh juga semakin rendah (Todaro \& Stephen, 2000). Gambar 3 menampilkan grafik laju pertumbuhan penduduk di ibu kota provinsi di wilayah Sumbagsel.

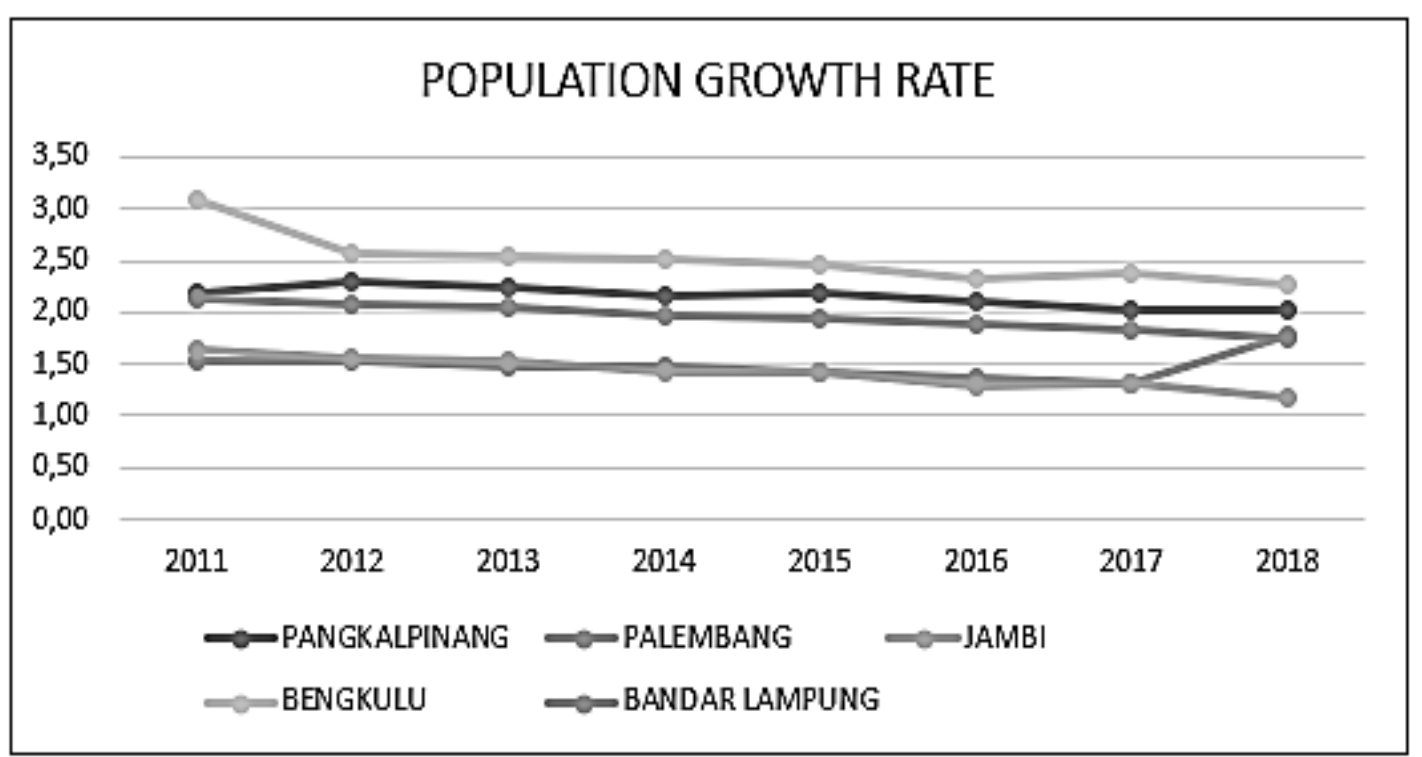

Sumber: Badan Pusat Statistik, diolah peneliti 2019

Gambar 3. Grafik laju pertumbuhan penduduk di Sumbagsel

Dari Gambar 3 dapat dilihat bahwa laju pertumbuhan penduduk tertinggi pada tahun 2018 berada di Kota Bengkulu yaitu sebesar 2,28 persen. Sedangkan laju pertumbuhan penduduk terendah pada tahun 2018 ada di Kota Jambi sebesar 1,18 persen.

Berdasarkan latar belakang yang sudah dijelaskan, maka penelitian ini akan membahas tentang pengaruh inflasi dan laju pertumbuhan penduduk terhadap kemiskinan di Sumatera bagian Selatan (Sumbagsel) tahun 2011-2018, studi kasus ibu kota provinsi wilayah Sumbagsel yaitu Palembang, Pangkalpinang, Bandar Lampung, Bengkulu, dan Jambi.

\section{METODE}

Jenis data yang digunakan adalah data panel yang diambil dari 5 ibu kota provinsi wilayah Sumatera bagian selatan periode tahun 2011 sampai 2018. 
Sumber data yang digunakan oleh penulis berasal dari data Badan Pusat Statistik (BPS).

Data panel atau pooled data adalah kombinasi dari data time series dan cross section. Jumlah observasi akan bertambah secara signifikan tanpa melakukan treatment apapun terhadap data. Dengan mengakomodasi informasi baik yang terkait dengan variabel-variabel cross section dan time series, data panel secara substansial mampu menurunkan masalah omitted variabel atau mengabaikan variabel yang relevan (Gujarati, 2012).

Residual dalam model regresi data panel mempunyai tiga kemungkinan yakni residual time series, cross section, maupun gabungan keduanya. Terdapat beberapa metode yang bisa digunakan untuk mengestimasi model regresi data panel, yakni sebagai berikut:

1. Common Effect Model (CEM) yakni teknik yang hanya mengkombinasikan data time series dan cross section. Dalam pendekatan ini, tidak memperhatikan dimensi individu maupun waktu.

2. Fixed Effect Model (FEM) yakni teknik yang memperhitungkan kemungkinan bahwa peneliti akan menghadapi masalah omitted variables dimana omitted variables ini mungkin membaca perubahan pada intercept time series atau cross section. Teknik fixed effect model ini menambahkan variabel dummy yang mengizinkan adanya perubahan intercept. Variabel dummy ini berguna untuk menangkap adanya perbedaan intercept antar individu dan antar waktu.

3. Random Effect Model (REM) yakni teknik dalam mengestimasi data panel yang memperhitungkan perbedaan antar individu dan antar waktu yang dicerminkan lewat intersep yang diakomodasi lewat error yang mungkin berkorelasi sepanjang cross section dan time series.

Adapun model data panel untuk masing-masing teknik regresi adalah sebagai berikut (Gujarati, 2012):

a. Common Effect Model (CEM)

$Y_{i t}=\beta_{1}+\beta_{2}+\beta_{3} X_{3 i t}+\ldots+\beta_{n} X_{n i t}+u_{i t}$

b. Fixed Effect Model (FEM)

$Y_{i t}=\alpha_{1}+a_{2} D_{2}+\ldots+a_{n} D_{n}+\beta_{2} X_{2 i t}+\ldots+\beta_{n} X_{n i t}+u_{i t}$

c. Random Effect Model (REM)

$Y_{i t}=\beta_{1}+\beta_{2} X_{2 i t}+\ldots+\beta_{n} X_{n i t}+\varepsilon_{i t}+u_{i t}$

Analisis regresi dengan data panel dapat dilakukan dengan beberapa langkah:

a. Pemilihan Model Estimasi Data Panel

Teknik analisis data panel dalam penelitian ini dapat dilakukan dengan metode common effect, fixed effect dan random effect, sedangkan untuk menentukan metode mana yang lebih sesuai dengan penelitian ini maka digunakan uji lagrange Multiplier, uji chow dan uji hausman. 


\section{b. Uji Statistik}

Model regresi terbaik dianalisis dengan dilakukan uji selanjutnya yaitu pengujian statistik dengan melakukan Uji Signifikansi Simultan (Uji Statistik F), Uji Parsial (Uji Statistik t), dan Uji Koefisien Determinasi $\left(\mathrm{R}^{2}\right)$.

Skema hubungan antara kemiskinan dengan variabel-variabel yang mempengaruhinya disajikan pada Gambar 4.

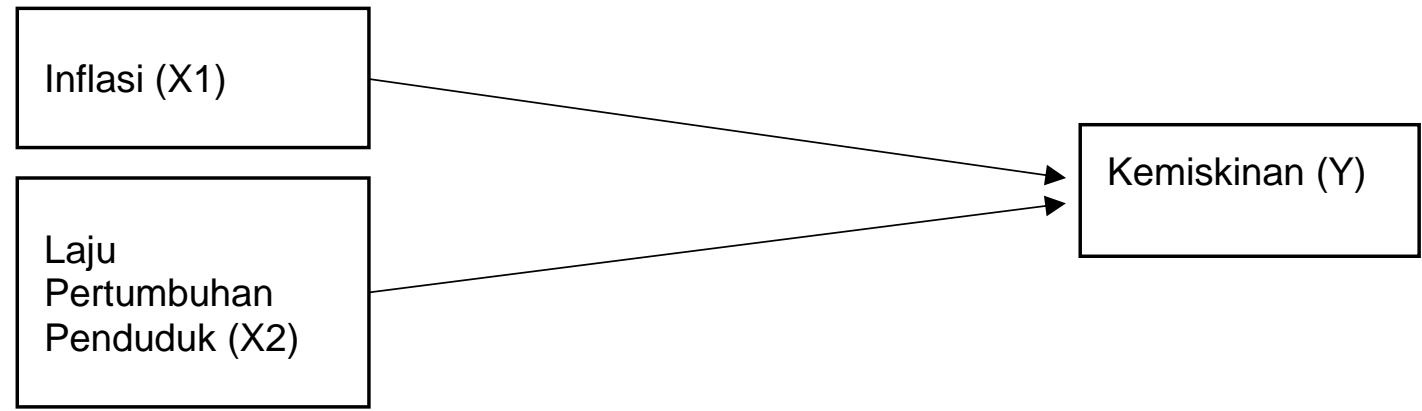

Gambar 4. Kerangka Pemikiran

Hipotesis yang dikembangkan dalam penelitian ini adalah sebagai berikut:

$\mathrm{H}_{0}$ : Inflasi (X1) dan laju pertumbuhan penduduk (X2) tidak berpengaruh terhadap kemiskinan $(\mathrm{Y})$.

$\mathrm{H}_{1}$ : Inflasi (X1) dan laju pertumbuhan penduduk (X2) berpengaruh terhadap kemiskinan $(\mathrm{Y})$.

\section{HASIL DAN PEMBAHASAN}

\section{Pemilihan Model}

Dalam melakukan analisis data pengaruh inflasi dan laju pertumbuhan penduduk terhadap kemiskinan di provinsi wilayah Sumatera bagian Selatan, pemilihan model dilakukan menggunakan analisis regresi data panel dengan 3 model yaitu common effect model, fixed effect model dan random effect model.

Untuk memilih model yang tepat antara common effect model dan fixed effect model digunakan Uji Chow. Sedangkan untuk memilih fixed effect model dan random effect model pengujian yang digunakan adalah melihat Uji Hausman. Uji LM digunakan untuk melihat atau membandingkan common effect model dan random effect model. Kemudian uji penaksiran modelnya tersebut dapat dilihat sebagai berikut:

\section{Uji Chow}

Dalam pengujian Uji Chow digunakan untuk membandingkan common effect model dengan fixed effect model. Hasil Uji Chow diperoleh probabilitas 0,000 dengan tingkat signifikan sebesar pada $\alpha=5 \%$. Nilai probabilitas $<0,05$ menunjukkan bahwa keputusan model yang digunakan dari hasil uji chow test ini adalah fixed effect model. 


\section{Uji Hausman}

Uji Hausman digunakan untuk membandingkan random effect model dengan fixed effect model. Dari hasil Uji Hausman didapatkan hasil dengan probabilitas sebesar 0,1021 . Sehingga nilai probabilitas $>0,05$ artinya model yang digunakan adalah random effect model.

\section{Uji LM}

Uji LM digunakan untuk membandingkan common effect model dengan random effect model yang dalam hal ini menggunakan cross-section dari BreushPagan.Berdasarkan pengujian yang telah dilakukan dengan nilai probabilitas sebesar $0,000<0,05$ yang berarti menolak $H_{0}$ dan menerima $H_{1}$. Sehingga model yang terbaik adalah random effect model.

\section{Uji Statistik}

Uji statistik dalam penelitian ini adalah koefisien determinasi $\left(R^{2}\right)$, uji statistik $F$ (simultan) dan uji statistik T (parsial).

\section{Uji Signifikansi Simultan (Uji F)}

Berdasarkan hasil analisis uji $\mathrm{F}$ (Tabel 1), diperoleh nilai F-hitung sebesar 5,835975 dan probabilitas $F$ sebesar 0,006267. Dalam taraf signifikansi 0,05 maka uji F signifikan. Sehingga dapat disimpulkan bahwa variabel inflasi dan laju pertumbuhan penduduk secara bersama-sama berpengaruh signifikan terhadap kemiskinan.

Tabel 1. Hasil Uji F

\begin{tabular}{ll}
\hline Uji Signifikan Simultan & \\
\hline R-square & 0,239809 \\
Adjust R-square & 0,198717 \\
F-statistic & 5,835975 \\
Prob (F-statistic) & 0,006267 \\
\hline
\end{tabular}

\section{Uji Parsial (Uji t)}

Hasil uji parsial pada Tabel 2 memberikan informasi sebagai berikut:

a. Pengaruh Inflasi terhadap Kemiskinan

Hasil analisis menunjukkan bahwa variabel inflasi memiliki t-hitung sebesar 0,050844 dan probabilitas sebesar 0,9597. Dalam taraf signifikansi 0,05 maka variabel inflasi secara individu tidak berpengaruh signifikan terhadap kemiskinan di provinsi wilayah Sumbagsel.

b. Pengaruh Laju Pertumbuhan Penduduk terhadap Kemiskinan

Hasil analisis menunjukkan bahwa variabel laju pertumbuhan penduduk memiliki t-hitung sebesar 3,461702 dan probabilitas sebesar 0,0014. Dalam taraf 
signifikansi 0,05 maka variabel laju pertumbuhan penduduk secara individu signifikan mempengaruhi kemiskinan di provinsi wilayah Sumbagsel.

Tabel 2. Hasil Uji t

\begin{tabular}{llll}
\hline Variabel & Coefficient & t-Statistic & Prob. \\
\hline Inflasi & 0,003267 & 0,050844 & 0,959 \\
LP Penduduk & 3,360733 & 3,461702 & 0,001 \\
C & 5,142642 & 1,947749 & 0,059 \\
\hline
\end{tabular}

\section{Koefisien Determinasi $\left(\mathbf{R}^{2}\right)$}

Berdasarkan hasil perhitungan koefisien determinasi atau goodness of fit pada uji $F$ diperoleh angka sebesar 0,239809. Hal ini menunjukkan bahwa variabel independen mampu menjelaskan variabel dependen sebesar 23,98 persen, sedangkan sisanya sebesar 76,02 persen dijelaskan oleh variabel lain yang tidak masuk dalam model.

\section{Hasil Estimasi}

Dari pengujian model yang telah dilakukan, maka diperoleh random effect model sebagai model terbaik dalam penelitian ini. Hasil ini dapat dilihat pada Tabel 3.

Tabel 3. Hasil Regresi Data Panel Random Effect Model

Method: Panel EGLS (Cross-section random effects)

Periods included: 8

Cross-sections included: 5

Total panel (balanced) observations: 40

\begin{tabular}{lcccc}
\hline Variable & Coefficient & Std. Error & t-Statistic & Prob. \\
\hline Inflation & 0.003267 & 0.064247 & 0.050844 & 0.9597 \\
Population Growth Rate & 3.360733 & 0.970832 & 3.461702 & 0.0014 \\
Constant & 5.142642 & 2.640300 & 1.947749 & 0.0591 \\
R-squared & 0.239809 & Mean dependent var & 0.896013 \\
Adj R-squared & 0.198717 & S.D. dependent var & 1.083201 \\
S.E. of regression & 0.969621 & Sum squared resid & 34.78610 \\
F-statistic & 5.835975 & Durbin-Watson stat & 0.660005 \\
Prob(F-statistic) & 0.006267 & &
\end{tabular}

Berdasarkan table, maka analisis regresi data panel dengan pendekatan random effect model diperoleh persamaan sebagai berikut:

Poverty $_{i t}=5.142642+0.003267$ Infl $_{i t}+3.360733$ PGR $R_{i t}+e_{i t}$ 
Keterangan:

Poverty $_{i t}=$ Kemiskinan

Infl $\quad=$ Inflasi

$P G R_{i t} \quad=$ Laju Pertumbuhan Penduduk

$e_{i t} \quad=$ error

Hasil estimasi menunjukkan bahwa inflasi tidak memberikan pengaruh terhadap kemiskinan. Hal ini tentunya tidak sejalan dengan hipotesis yang mengatakan bahwa inflasi memiliki pengaruh terhadap tingkat kemiskinan dan teori dimana inflasi berpengaruh positif terhadap kemiskinan. Inflasi di Provinsi wilayah Sumatera bagian Selatan cenderung berfluktuatif dan tidak terjadi dalam jangka waktu yang lama. Hal ini tentu masih dapat dikendalikan oleh pemerintah sehingga kenaikan tingkat kemiskinan yang disebabkan oleh inflasi tidak terjadi.

Selanjutnya laju pertumbuhan penduduk memberikan pengaruh terhadap kemiskinan. Dari hasil estimasi dapat disimpulkan, kenaikan laju pertumbuhan penduduk sebesar 1 persen akan meningkatkan kemiskinan sebesar 3,36 persen. Hal ini menunjukkan bahwa besarnya laju pertumbuhan penduduk di provinsi wilayah Sumatera bagian Selatan tidak diimbangi dengan kemajuan faktor-faktor perkembangan yang lain. Dengan demikian, meningkatnya laju pertumbuhan penduduk justru akan menurunkan tingkat upah dan menyebabkan jumlah penduduk miskin semakin bertambah.

\section{KESIMPULAN}

Berdasarkan hasil penelitian ditemukan bahwa inflasi tidak berpengaruh signifikan terhadap kemiskinan di Provinsi Sumatera bagian Selatan karena inflasi cenderung berfluktuatif dan tidak terjadi dalam waktu yang lama sehingga masih dapat dikendalikan oleh pemerintah. Temuan lainnya adalah laju pertumbuhan penduduk memberikan pengaruh yang positif dan signifikan terhadap kemiskinan di Provinsi Sumatera bagian Selatan, yang berarti kenaikan laju pertumbuhan penduduk akan menyebabkan tingkat kemiskinan meningkat. Hal ini menunjukkan bahwa besarnya laju pertumbuhan penduduk di Provinsi Sumatera bagian Selatan tidak diimbangi dengan faktor-faktor perkembangan yang lain sehingga akan menurunkan tingkat upah dan jumlah penduduk miskin akan bertambah. 


\section{DAFTAR PUSTAKA}

(1) Arsyad, L. (2010). Ekonomi Pembangunan. Yogyakarta, Indonesia: UPP STIM YKPM.

(2) Badan Pusat Statistik. (2019, June 20). https://bps.go.id

(3) Dumairy. (1996). Perekonomian Indonesia, Jakarta. Indonesia: Erlangga.

(4) Fatria, M. (2020). The Effects of Physical and Non-physical Investments of Government Expenditure in Education and Health Sectors on Human Development Index in Pekanbaru City. Indonesian Journal of Economics, Social, and Humanities, 2(1), 65-77. https://doi.org/10.31258/ijesh.2.1.65-77

(5) Gujarati, DN \& Dawn, CP. (2012), Dasar-dasar Ekonometrika, Edisi Kelima Buku 2, Terjemahan oleh Raden Carlos Mangunsong. Jakarta, Indonesia: Salemba Empat.

(6) Irhamni. (2017). Pengaruh Jumlah Penduduk, Pengangguran, dan Pengeluaran Pemerintah Terhadap Kemiskinan di Indonesia Tahun 1986-2015 [Undergraduate Thesis]. Fakultas Ekonomi, Universitas Negeri Yogyakarta. Indonesia.

(7) Isramiwarti, R., Rasuli, M., \& T. Taufik. (2017). Pengaruh Pendapatan Asli Daerah, Dana Alokasi Umum, Dana Bagi Hasil, dan jumlah penduduk terhadap tingkat kemiskinan dengan Belanja Daerah sebagai variabel intervening pada Kabupaten/Kota di Provinsi Riau tahun 2011 S.D 2015. PEKBIS (Jurnal Pendidikan Ekonomi dan Bisnis), 9(3), 195-213. https://pekbis.ejournal.unri.ac.id/index.php/JPEB/article/view/4634

(8) Nasikun. (2001). Diktat Mata Kuliah, Isu dan Kebijakan Penanggulangan Kemiskinan, Magister Administrasi Publik. Yogyakarta, Indonesia: Universitas Gadjah Mada.

(9) Noripin. (2009). Ekonomi Moneter, Buku II, Edisi ke-1. Yogyakarta, Indonesia: BPFE.

(10) Nugroho, I \& Dahuri, R. (2012). Pembangunan Wilayah: Perspektif Ekonomi, Sosial, dan Lingkungan. Jakarta, Indonesia: LP3ES.

(11) Suliswanto, MSW. (2010). Pengaruh Produk Domestik Bruto (PDB) dan Indeks Pembangunan Manusia (IPM) Terhadap Kemiskinan di Indonesia. Jurnal Ekonomi Pembangunan, 8, (2), 357-366. https://doi.org/10.22219/jep.v8i2.3610

(12) Syahza, A., Bakce, D., \& Asmit, B. (2018). Natural rubber institutional arrangement in efforts to accelerate rural economic development in the province of Riau. International Journal of Law and Management, 60(6), 1509-1521. https://doi.org/10.1108/IJLMA-102017-0257

(13) Taryono, lyan, R.Y., \& Ningsih, R.B. (2009). Studi Tentang Migrasi Dan Implikasinya Terhadap Kemiskinan Di Kabupaten Pelalawan. Jurnal Ekonomi, 17(2), 120-131. https://je.ejournal.unri.ac.id/index.php/JE/article/view/728

(14) Todaro, MP \& Stephen, CS. (2000). Pembangunan Ekonomi di Dunia Ketiga Edisi Ketujuh. Jakarta, Indonesia: Erlangga.

(15) Zebua, W.N., Bakce, D., \& Hadi, S. (2015). Analisis Faktor-faktor Dominan yang Mempengaruhi Kemiskinan di Provinsi Riau. IJAE (Jurnal Ilmu Ekonomi Pertanian Indonesia), 6(2), 158-167. https://ijae.ejournal.unri.ac.id/index.php/IJAE/article/view/3459

(16) Zebua, Y.A., Restuhadi, F., \& Hadi, S. (2017). Analisis Faktor-faktor Kemiskinan Kabupaten di Sumatera. Berkala Perikanan Terubuk, 45(3), 57-66. http://dx.doi.org/10.31258/terubuk.45.3.57-65 